\title{
The Treatment of HIV by Vibrational Herbal Medicine
}

\author{
Almoez LeDinEllah M. S. Eltouny* \\ The National Center for Research, Egypt \\ *Corresponding Author: Dr. Almoez LeDinEllah M. S. Eltouny, The National Center for Research, Egypt, Tel: \\ 0020-2-359-2083; E-mail: eltounya@hotmail.com
}

Received: 22December 2018; Accepted: 28December 2018; Published: 21 January 2019

\begin{abstract}
The study determines the type of virus, not as a simple but as a set of complex virus system composed of three different complex virus systems. The study also relates how the HIV virus has different energy characteristics not similar to other well known viruses. The energy characteristics of HIV indicate two positive and two negative energy groups. "Normal" viruses, like Hep C, has four negative energy groups. It was finally determined that the cause for the presence of positive and negative energy groups lies in the fact that HIV is composed of three different Major Complex Virus groups and not one monolithic Major Complex Virus like Hep C. All three complex virus systems have to be eliminated to eliminate the HIV virus. Many vibrational herbal mixtures were made over the course of the last 14 years and tried, physically and by simulation, on several patients. The results were mixed until it was discovered that the virus is actually three complex systems in one. Each of the trial mixtures worked on one or two, and not totally fully, on all three systems. The results of our study of the Berlin patient and the Mississippi baby indicate that two of the three viruses were eradicated. Although the main virus in both was the same, the second was different in each, leaving the third virus system untouched. Our latest Vibrational Herbal Mixture eradicates all three complex virus systems, as opposed to the latest chemical experimental treatment which will eliminate the main complex system but will leave the other two, untouched. This may lead to false results as a patient appears to be cured and then the virus reappearing just like the case of the Berlin patient.
\end{abstract}

Keywords: HIV virus; Vibrational Herbal Mixture; Chemical medicines 


\section{Introduction}

The Ancient Chinese discovered that ailments of the human body are the result of an increase or a decrease in the vital energies flowing in the energy paths of that body. Their objective became to bring these energies into balance in order to heal or cure the specific ailment. They knew that the energy had to be manipulated to become more or less, depending on the ailment. There was one basic challenge, they could not measure the increase or decrease of that energy. They did not appear to have a measuring device to do that and were unable to overcome this challenge. Around that time, or probably earlier, the Ancient Egyptians made the same discovery, however, they had a device to measure the changes occurring in the level of energy they were measuring. These energies are unseen energies flowing through the body and affecting every single part or organ of that body.

The device that they made was the Universal Pendulum [1]. This pendulum, and other shapes and forms of it are seen until today on the walls of the temples in KomOmbo, Edfu and other temples still standing in Egypt. There is a whole section of Pendulum Exhibits in the Louvre in Paris.This Pendulum in the hands of a practiced Adept or Practitioner, can open inroads in discovering the ailments in the human body or "see" the hidden flow of energy through the human body and the changes that occur. One of the first scientists to study these energies were theFrench scientists:"Chaumery" and "Belizal" in mid 1960's [2]. All our studies are conducted using a Universal Pendulum and using the technique I devised to measure the changes of energy due to changes in the condition of the patient under study. This technique is detailed in the bibliography [20]. Through this technique, we have been able, over the last twenty years, to come to measure the energies of any entity in the body ie; a virus. This Pendulum can measure the energy of a virus unseen by modern science and its effects and the effects of a medicine on that virus or ailment, measuring the increase or decrease of the energy associated with that virus or ailment if subjected to that medicine.

The procedure used may not conform to scientific research parameters used in our modern research laboratories, but this is a totally different science and will produce significant and plausible results. It has helped in measuring the results of new treatments, without actual testing using theoretical testing, since it will measure the changes of the energy of the medicine as it reacts with the energy of the specimen, without the patient ingesting any of it. One may even choose among several chemical medicines for the same ailment in order to obtain the best effective treatment.

\section{Description}

This herbal approach is based on ordinary herbs mixed together in fixed proportions in specific herbal mixtures that are designed to heal a certain ailment as they have a certain affinity to them. Although the mixtures are totally herbal, the effects of the herbs are not determined by the physical and chemical properties of the herbs in the mixtures, but on the vibrational properties of the herbs. This technique was discovered by accident, and may have been used by the Ancient Egyptians and the Ancient Chinese. 
We have been able to discover the underlying rules governing the usage of herbs in Vibrational Herbal Medicine. These rules and regulations were published as a paper called "The Rules of Ancient Wisdom and Herbal Medicine"(20). The important fact to consider is that these mixtures are basically safe herbal mixtures, since the herbs used are safe, noncontroversial, effective and actually affect the patient positively, eliminating the effect of the illness or reducing its effects appreciably, without any side effects to mention.

These followed the main Rules of the Laws of Ancient Wisdom.(20)

1. Everything in the universe is alive and therefore has energy that can be measured.

2. EachHerb has an energy level that can be measured.

3. The healing qualities of herbs depend on their vibrational qualities and not only on their chemical or physical properties.

4. The energy characteristics of the herbal mixture have different vibrations than those of its sum of constituents.

\section{Utilization}

This technique, through the ability to measure the vibrational energy of organs of the body, and the changes occurring in them, as a result of an ailment or disease, also allows the practitioner to be able to recognize the presence of viruses and to be able to measure their energy level changes, i.e., the changes brought about by the herbal medicine taken by the patient on the energy of the virus and on the patient. This is usually apparent when using the medicine on a specimen of the patient, and before the patient actually takes the vibrational herbal medicine. This approach has helped in formulating herbal mixtures that are designed to attack specific viruses, gradually eliminating the virus and curing the patient. These mixtures are patentable and are protected under international copyright laws. Over the past twenty years we have been able to study and prepare treatments and cures for several lethal ailments, which have been discovered to be viral in origin.

\section{Description of Viruses in VHM}

Everything in the Universe is alive. Every living being has a specific energy pattern, similar to what we know as DNA.There are four main energies or vibrations that characterize the energies in the Universe. We will use the Chinese notations for them as they are recognized all over the world. These energies were known by the Ancient Egyptians but using other notations that are totally unknown to the general population. These are represented by the symbol of the Ankh, where each of its sides represents one of the four main Chinese energies.

These are four main types of Energy (20):

1. "Chi" or "Qui" denoted by $\mathrm{Q}$ which is potential-neutral,

2. "Yin" denoted by "Yn"is a feminine energy,

3. "Yang" denoted by "Yg" is a masculine energy,

4. "Omega" denotedby " $\Omega$ " is a neutral energy of wellbeing 
Omega was not mentioned in the literature, but was discovered in the course of my work in Vibrational Herbal Medicine.These vibrations are either positive or negative. We have devised a system of measurement, as a means of comparing the same energy types. Each of these energies ranges from +100 to -100 , except for Omega, which ranges from +38 to $-38(20)$. Through our study of the energies of complex virus systems, we have discovered that these viruses are characterized by energy groups. Our initial understanding was that all energy groups of a virus were all negative. This theory was challenged when repeated checks of the HIV virus indicated otherwise. Accordingly, virus systems are characterized by four energy readings. They could be all negative, such as that of Hepatitis $\mathrm{C}$ virus, or two positive and two negative as that of HIV.The Vibrational Herbal Mixtures made are aimed towards the gradual elimination of the group energy of the virus over a period of time. This is manifested in a gradual improvement in the condition of patients in some viruses until the patient is cured, while in other virus systems, there may not be a change until the virus is totally eradicated.

\section{HIV}

We started working in finding a cure for HIV, early in 1999, several years after starting the research for a cure for Hepatitis C. From the vibrational point of view, the mode of operation of both viruses appeared similar. Although the mode of operation of the viruses appeared similar, their characteristic energy signals were quite different.Viruses are characterized by four main energy groups or vibrations. Whereas the energies of Hepatitis $\mathrm{C}$ are all negative, the classic virus energy signal; that of HIV, gave a different signal all together. The Chi and Omega energies are negative while Yin and Yang energies are positive. This characteristic may be the reason that the immune system, which recognizes a virus as composed of four negative energy groups, may not understand this new intruder with two positive and two negative groups. Once the virus enters the body, the immune system is helpless to resist it and it moves with impunity within the body.

Since HIV patients in Egypt are extremely difficult to find, and once found, are quite reluctant to admit having the disease, all refused to take or try the treatment since it indicated a tacit admission of having the disease. Clinical testing the treatments made for HIV on HIV patients proved impossible for several years. However, we had three different patients with HIV, but who were not Egyptian. The first was "Marcel", the second was "Francois" and the third, "Joe". The results are indicated in the table [1]. The three were quite willing to try the treatments as they were of herbal base and did not threaten any adverse side effects. The actual results proved that correct. Originally, we sent the medicine via relatives or friends of the patients, but were not allowed to send them by courier or mail, as much information would be revealed. Their request for medicine was continued as the test results, (as I was told) indicated progress, by a reduction in the viral load of two of the patients. After 9/11, everything stopped and we were not able to mail any herbal medicine or sent it by courier. We searched passionately for Egyptian patients, so as to overcome the problem of shipping. No one patient was even willing to try the treatment or talk to us or acknowledge having HIV. One young engineer (Mo) (Table 1)) was introduced to us with HIV and desperately wanted to be cured. After given the first course of treatment for 30 days, we discovered that he was not taking the treatment and had stopped after just a few days.After a long struggle to contact him, he explained that he stopped 
taking the treatment in case that it did not work, he would be devastated. This is an illogical premise, but was seen in many patients especially in the early days of Hep.C treatments. Although he took the medicine for about ten days, the results are still apparent and he is still alive.

For several years we were not able to ascertain the structure of the HIV virus as we did not have any specimens from patients to investigate. During the course of our studies in Hepatitis $\mathrm{C}$ research, we discovered that since it is energy and vibration that we are measuring, the energies of the photograph, as a specimen, of the patient reflected an excellent image of the condition of the patient and the virus within. This technique is similar to the technique of the witness, used in radesthesia, and used in testing this and all other treatments (1). This discovery helped greatly in our research to discover the secrets of HIV and made our research emphasis on finding the photographs of patients instead of the actual patients.

\section{Structure of the HIV Virus}

The first assumption of the structure of the HIV virus is described in the article written in 1999 and published in 2001(20).The main assumption was that a main complex virus was divided into several main groups. Today, we have reached other conclusions. The virus is a Multi Complex Virus System, composed of billions of main complex virus groups that are in exact proportions in each strain of the virus. According to our recent findings and our readings, the HIV virus is divided in three major parts or three different virus systems. Part $\mathrm{A}$ is the most active component of the virus, which is about 46 percentage of the total strain of the virus; the other two components, components B and C may not be active immediately, but may appear later on. As a test for our theory, we studied the structure of the HIV virus of the Berlin patient (4), as the first patient who was pronounced free of HIV.

In studying the condition of the Berlin patient, we tested, by simulation, the effects of some of our herbal treatments for each of the three components identified previously.Some of the components did not respond to some of the treatments, indicating that some of the active components were eliminated. However, sometime after being declared cured of HIV, the Berlin patient started developing some active viral load. This load was lower than the original but still present. One of the leading practitioner in the HIV treatments suggested that the patient may have been reinfected(3). Our tests indicated that a small percentage of the HIV virus was active: about $17 \%$. What is quite interesting is the fact that the results of the tests of the Mississippi Baby, the second patient to be declared free of the HIV virus [4], are exactly the same as that of the Berlin patient, with an active component of $17 \%$.

On further scrutiny, it was discovered that the Berlin patient had one active complex virus system that was active and gave the $17 \%$ compared to the whole 3 system virus group as described by us. Similarly, the Mississippi baby(4) gave the same indication. This has led us to confirm our belief that the HIV virus is composed of three main Complex virus systems; one is the main system which is active from the start and which is apparent to researchers where the other two may or may not appear soon after the elimination of the main Complex virus system.

Some of our designed herbal mixtures, over the years, dealt mainly with the main component, while others 
eliminated parts of each, until we were able to design one mixture to eliminate all the components together and another group to eliminate each component separately. These mixtures were tested, by simulation, on other patients and the results were quite positive. We had treated a few patients over the years with some of these mixtures and the results were measurable even after close to ten years, indicating which component that was affected. Other patients, who were not treated, but were tested in simulation, responded quite well and totally, to the simulated tests, indicating complete elimination of the HIV virus, in some of the patients. The main objective of our research is to eliminate each of these virus groups and finally the whole virus. The reaction of the virus, as a living organism, to the introduction of a treatment, may be different in each case. It may be an increase or a decrease in the viral load or no change at all, but the aim is complete elimination of the main components of the virus.

\section{Treatment}

\subsection{Treatment with one mixture}

The treatment is composed of one main Vibrational Herbal Mixture (VHM) that is taken daily. This mixture is composed of ordinary herbs that are not controversial, that are present in acceptable pharmacopeia, and do not cause threat to human life. These are the same herbs used safely in the treatment of Hepatitis $\mathrm{C}$, but the combinations and proportions are different.The dose for the mixture is two 900mg capsules taken once daily. They are timed to be after lunch, or after dinner. The main thrust of this mixture is the elimination of the components of the virus, and each day eliminates part of the virus. This mixture can be taken with other chemical treatments, with the condition that there is a period of half an hour between the VHM capsules and any other medication. The duration of the treatment is about 65 days. There is a new treatment which was designed lately, to reduce the time of treatment and the effectiveness of the treatment. We are certain of the fact that this mixture will eliminate a large percentage of the HIV virus, not less than $80 \%$ and more likely to reach $100 \%$. Our confidence in these statements stems from the results that we have seen with Hepatits $\mathrm{C}$ patients, Leukemia patients and Cancer of the Liver patients. The same technique was used in the treatments of the above ailments.

\subsection{Treatments containing two herbal mixtures}

In treatments containing two herbal mixtures, the dosage is divided to be taken after two main meals. The duration depends on which mixture is used. The duration of the treatment is 35 days for each of the mixtures. It is preferable to have a viral load test made before the start of the treatment to serve as a bench mark for the treatment. The main objective is the elimination of all three components of the HIV Virus.

\section{Comments}

There are 2 publicized patients that have been allegedly cured of HIV, according to information published. These are

a) Timothy Brown, theBerlinPatient (BP)(3)

b) The Mississippi Baby (MB)(4) 
These are the two references that are used for comparison with infected patients with HIV and who are used in our simulation trials to assess the efficacy of any treatment. Lately, the Berlin Patient exhibited signs of the recurrence of the HIV virus in him. This has led to speculation as to whether he has been re-infected or that the virus was not totally eliminated in the first place. In our study of the Berlin patient's case, based on our understanding of the composition of the HIV virus, according to our Energy theory, there are three main components of the HIV virus:

Component A:Which is the main component, is active and affects the viral load and composes about $46 \%$ of the whole virus.

Component B:Which is the second component, may not be active at the same time as component A. It becomes active sometime later, when the main component may be affected. This is about $27 \%$ of the whole virus.

Component $\mathrm{C}$ :This is the third part of the whole virus, which may not be as active as the first component. It is important to note the difficulty of determining which of the components compose what part of the viral load. This is about $27 \%$ of the whole virus.

In our analysis of the condition of the Berlin Patient, to determine whether or not this infection is a new one or is it part of the old infection that was not eliminated; we discover that Component A of the virus was eliminated at $100 \%$, component B was eliminated at $100 \%$, while component $\mathrm{C}$ was only eliminated at $56 \%$, according to our energy analysis of the virus. This in total indicates that the BP is $87 \%$ free of the virus and not totally as originally thought, leaving a mere $13 \%$ of the HIV virus active and appearing in the viral loads. However, it should be stressed that the power of this component is not that great, and that it barely affects the viral load and only after component A is totally eliminated. In our analysis of the Mississippi Baby, we discovered that Component A was eradicated by $100 \%$, component $\mathrm{C}$ was eradicated $100 \%$, while in component $\mathrm{B}$ only $56 \%$ of the virus were eliminated. This, in total, indicates that the Mississippi Baby is only $87 \%$ free of the HIV, on the average, and may develop some viral load, if not already active. This analysis leads us to believe that regardless of whether component $\mathrm{B}$ or $\mathrm{C}$ of the HIV virus are still alive, the virus is not totally eradicated and that the main component $\mathrm{A}$ is the one component that has to be eliminated first to cause a marked difference in the viral load and then eliminate the other two components, as they will become active and cause a positive viral load. Otherwise, as we have seen, our VHM treatments act on all 3 components simultaneously from the beginning.

In comparing the results of the Berlin Patient and the Mississippi Baby, Component A is the one that is totally eradicated, and it appears to be the controlling factor of the whole virus. Once this is eliminated, components B and $\mathrm{C}$ have to be eliminated to complete the job.There are three main components composing the whole power of the HIV virus, we can either eliminate the three at once, or each one separately. We have treated several patients over the last 12 years, with different (VHM) mixtures designed to eliminate as much of the HIV virus as we could. All these people are still alive. From reexamination of their photographs, we believe that most have not taken any new medicines that eliminate any parts of the components of the virus, according to our readings. However, it appears 
that each treatment, of our herbal mixtures, eliminated a part of one of the three components of the HIV virus and can still be measured. During all the previous years, we were under the impression that HIV virus contains one type of Multi-Complex Virus System, even though they may be in clusters, but lately discovered that there may be three components composing the virus as described above. This may have been the reason we were not able to reach a treatment before now.

In order to prove or disprove this theory, we examined all the results of all the patients who took even one course of herbal treatment over the last twelve years. This would reveal the effects of each treatment on each patient and on each component of the virus if any. This is shown in table (2) following.

One person, not a patient, but a famous US actor, whose name is left out,is placed in the table as an example of someone who has not been treated by any of our herbal treatments nor, as far as we know, by any medicine that affects component A of the virus, until now. Following is a table comparing the results, theoretically, of several of the patients and comparing them to taking the new Drug X being tried by a major pharmaceutical company, using our simulation techniques. Another table indicates the results of one of our treatments FHIV611 and comparing it to a new drug(X) by a leading pharmaceutical company Table 2 .

\begin{tabular}{|l|l|l|l|}
\hline Patient Name & Component A & Component B & Component C \\
\hline \begin{tabular}{l} 
"Joe" $\begin{array}{l}\text { Canadian male } \\
\text { Mid thirties }\end{array}$ \\
\cline { 2 - 5 }
\end{tabular} & $19 \%$ & $0 \%$ & $0 \%$ \\
\hline $\begin{array}{l}\text { "Marcel" } \\
\text { French male } \\
50 \text { years old }\end{array}$ & $44 \%$ & $0 \%$ & $0 \%$ \\
\cline { 2 - 5 } & & $0 \%$ & $0 \%$ \\
\hline $\begin{array}{l}\text { François" } \\
\text { Early thirties }\end{array}$ & $68 \%$ & $0 \%$ & $0 \%$ \\
\hline $\begin{array}{l}\text { Mo } \\
\text { Egyptian male } \\
29 \text { years old, }\end{array}$ & $\begin{array}{l}\text { FHIV611 in } 65 \text { days at } 1800 \\
\text { mg per day100\%eliminated }\end{array}$ & $\begin{array}{l}\text { FHIV611 in } 65 \text { days at } 1800 \\
\text { mg per day100\%eliminated }\end{array}$ & $\begin{array}{l}\text { FHIV611 in } 65 \text { days at } 1800 \\
\text { mg per day } 100 \% \text { eliminated }\end{array}$ \\
\cline { 2 - 5 } & & $\%$ & $1 \%$ \\
\hline
\end{tabular}

This statement does not mean that the medicine was given for ten years, butvery little over a ten year period for the different patients.

Table 1:Indicating the results of taking Herbal Treatment for some patients over ten years, and comparing with taking one of our treatments FHIV611. 


\begin{tabular}{|l|l|l|l|l|l|}
\hline Patient Name & Treatment & $\begin{array}{c}\text { Component } \\
\text { A }\end{array}$ & $\begin{array}{l}\text { Component } \\
\text { B }\end{array}$ & $\begin{array}{c}\text { Component } \\
\text { C }\end{array}$ & Virus \% \\
\hline $\begin{array}{l}\text { "Joe" } \\
\text { Canadian male } \\
\text { Mid thirties }\end{array}$ & $\begin{array}{l}\text { Drug X dose 1 tablet } \\
\text { per day for 125 days }\end{array}$ & $100 \%$ & $0 \%$ & $0 \%$ & This is 46\% of total virus \\
\hline $\begin{array}{l}\text { "Marcel" } \\
\text { French male } \\
50 \text { years old }\end{array}$ & $\begin{array}{l}\text { Drug X dose 1 tablet } \\
\text { per day for 125 days }\end{array}$ & $100 \%$ & $0 \%$ & $0 \%$ & This is 46\% of total virus \\
\hline $\begin{array}{l}\text { "François" } \\
\text { French male } \\
\text { Early thirties }\end{array}$ & $\begin{array}{l}\text { DrugX dose 1 tablet } \\
\text { per day for125 days }\end{array}$ & $100 \%$ & $0 \%$ & $0 \%$ & This is $46 \%$ of total virus \\
\hline $\begin{array}{l}\text { Charlie } \\
\text { U.S. male } \\
55 \text { years old }\end{array}$ & $\begin{array}{l}\text { Drug X dose1 tablet } \\
\text { perDay for 125 days }\end{array}$ & $100 \%$ & $0 \%$ & $0 \%$ & This is $46 \%$ of total virus \\
\hline
\end{tabular}

Table 2:Drug ' $X$ " as the testing medicine and its theoretical effect on patients by Simulation.

\begin{tabular}{|l|l|l|l|l|l|}
\hline $\begin{array}{l}\text { Patient } \\
\text { name }\end{array}$ & $\begin{array}{l}\text { Type } \\
\text { of drug }\end{array}$ & ComponentA & ComponentB & ComponentC & FHIV611 \\
\hline $\begin{array}{l}\text { Timothy } \\
\text { Berlin } \\
\text { patient }\end{array}$ & Drug X & No reaction & No reaction & $\begin{array}{l}\text { No reaction } \\
\text { with drug X X } \\
17 \% \text { active }\end{array}$ & $\begin{array}{l}\text { Eradicates the remaining part of } \\
\text { Component C }\end{array}$ \\
\hline $\begin{array}{l}\text { Mississippi } \\
\text { Baby }\end{array}$ & Drug X & No reaction & $\begin{array}{l}\text { Noreaction with } \\
\text { drug x } 17 \% \text { active }\end{array}$ & No reaction & $\begin{array}{l}\text { FHIV611 eradicates the } \\
\text { remaining part of Component B }\end{array}$ \\
\hline
\end{tabular}

Table 3: Effects of Drug X on BP and the Miss. Baby and effects of VHM FHIV611.

\begin{tabular}{|l|l|l|l|l|}
\hline Name of Herb & Q “Chi” & Yin 'YN” & Yang “Yg” & Omega \\
\hline Ginger root & 90 & 90 & -90 & 36 \\
\hline Lupin & -90 & 0 & 0 & 36 \\
\hline Cinnamon & 90 & 90 & 90 & 36 \\
\hline All Spice & 90 & 90 & 90 & 36 \\
\hline Willow leaf & -90 & 0 & 0 & 36 \\
\hline Korean Ginsing & 90 & 90 & 0 & 36 \\
\hline Garlic, Chinese & 90 & 0 & 90 & 36 \\
\hline Parsley Seeds & -90 & 90 & 90 & 36 \\
\hline
\end{tabular}

Table 4: Name of some of the Herbs used in Vibrational Herbal Medicine and their Vibrational Qualities.

\begin{tabular}{|l|c|}
\hline $\mathrm{Q}=$ & -96 \\
\hline $\mathrm{Yg}=$ & 96 \\
\hline $\mathrm{Yn}=$ & 96 \\
\hline Omega $=$ & -36 \\
\hline
\end{tabular}

Table 5:The Vibrational Energy Characteristics of the FHIV 612 Treatment for HIV. 


\begin{tabular}{|l|l|l|}
\hline Vibrational Energy & Patient 1 & Patient 2 \\
\hline $\mathrm{Q}=$ & -90 & -40 \\
\hline $\mathrm{Yn}=$ & 75 & 25 \\
\hline $\mathrm{Yg}=$ & 80 & 20 \\
\hline Omega $=$ & -30 & -20 \\
\hline
\end{tabular}

Table 6:The Characteristics of the Energy of the HIV virus in two different patients.

Patient 1: was one of my patients (Mo), living in Egypt and took the herbal medicine, presumably for 5 weeks, but actually took them for a few days. He promised a couple of times after that to take the first part, the five week course, then, we would reevaluate his condition. His main reason for not taking the medicine, which he admitted did not have any side effects; was his fear that it would not work and he would not be able to face those facts. This was not the first time I had faced that argument, as I had with one of my female patients in the Hep C trials. This treatment was given five years ago. His condition did not appear to be deteriorating, and he may be in one of the support programs to help HIV patients in Egypt maintain their stable health status.

Patient 2:The second patient, a famous Hollywood actor, appears to be taking a new chemical medicine, as his statistics have improved beyond any accidental change from a previous control.that we made several months ago.

This new Herbal Medicine FHIV 612, is designed to eliminate all of the three components composing the active part of the HIV Virus in an additional 35 days for patient 2, and another 55 days for patient 1 to reduce the viral load to non- detectable levels in both patients, or any patients for that matter, based on our simulation testing.

\section{Conclusion}

1. The HIV virus is not a "normal virus" similar in structure to the Hepatitis C viral virus.

2. The HIV virus exhibited a unique characteristic in its energy signature in that it had two positive and two negative energy groups.

3. Whereas most virus systems are composed of a Complex Virus system composed of billions of small clusters of the virus, even though they have different replication rates, they are from one virus.

4. The HIV Virus, on the other hand, iscomposed of three main complex virus sytems that are different but cause the HIV action.

5. It is not clear whether each one of these three main complex virus systems attacks one part of the body or each, as it becomes active, attacks a specific part of the body.

6. The results of the Mississippi Baby and the Berlin Patient as having a relapse due to a new infection or otherwise, may be attributed to one of the three main complex virus systems becoming active, but indication of a new infection.

7. The main contributor tothe destructive power of the HIV virus isComponent A (Complex Virus System 1) and causes the large part of the replication rate of the viral load as long as the component A is still active.

8. To totally eliminate the HIV Virus, one has to eliminate all three main components totally. 
9. There are clinical trials in the market to produce a cure for HIV, but currently, the one promising treatment, although it reduces the viral load greatly, it usually eliminates Component A and one of the two remaining components.

10. We have been able to design a Vibrational Herbal Medicine $\{\mathrm{VHM}\}$ to totally eliminate all three main components simultaneously and thus reach a zero viral load, this is mixture FHIV 612, and has been reached in simulation trials.

The VHM is totally safe to take with no adverse side effects and does not react or interfere with any chemically based maintenance drug treatment, when taken three hours after or before such medication.

\section{References}

1. YourFirstSteps in Dowsing. ByDrKhalilMessiha,Copyrightby Dr. KhalilMessiha, GEBO,Cairo, Egypt. Catalog No: 11293-93, ISBN 977-00-6342-8.

2. L. Chaumery et de Belizal, Essai De Radiesthetie Vibratoire. Edition Dangles, 38 Rue Moscou. Paris (8).

3. https://www.niaid.nih.gov/news-events/mississippi-baby-now-has-detectable-hiv-researchers-find

4. The Berlin patient(https://www.reuters.com/article/us-aids-cure-idUSBREA010B520140102

5. Secrets of thePharoahs (TheScience of Radethesia), ByDawood Khalil Messiha. BScSeries of Science and Life (152) (The General Authority of Book Printers, Egypt.

6. British Herbal Compendium. Peter R. Bradley. Publishedby British Herbal Medicine Association1 (1992).

7. Over-the-Counter Herbal Medicine byPenelopeOdy.PublishedbyKyleCathieLimited(1996).

8. TheEncyclopedia of Medicinal Plants, by Andrew Chevallier MNIMH. DorlingKindersley(1996).

9. Varro E. Tyler. TheHonest Herbal.PharmaceuticalsProducts Pres. An Imprint of theHaworthPress, Inc. New York, ThirdEdition.

10. Christopher Robbins. TheHousehold Herbal. BantamBooks(1997).

11. PenelopeOdy. The Complete Medicinal Herbal. DorlingKindersly, Limited London (1995).

12. WrenRC, SaffronWaldenFLS.Potter's New Cyclopedia of BotanicalDrugs\&Preparations.The C.W. Daniel CompanyLimited.

13. Daniel B. Mowrey. TheScientificValidation of Herbal Medicine. Keats Publishing, Inc., New Canaan, Connecticut.

14. John F. Nunn. AncientEgyptian Medicine. British MuseumPress(1996).

15. Hassan Kamal. Ancient Egyptian Medicine. MadbouliPress, Cairo (1991).

16. Ahmed ZoheirAmin. AnAncientEgyptian Herbal, Lise Mannicke, Translation. MadbouliPress Cairo

17. Dawood Al Antaky. Dawood's Ticket, Arabic Center forPrinting and Publishing, MaaroufBros, Cairo.

18. Mahmoud Malla. HowtoTreatYourselfwithHerbs. RashadPress, Lebanon

19. Dar Al Behar. HealYourselfwithHerbs, Lebanon

20. Eltouny, Almoez, "Laws of AncientWisdom", Explore Magazine year 11, Prescott, Arizona. (2001).

21. Dar Al Fikr. Herbs and Medicinal Plants. PreparedbySalamFawzi, Beirut, Lebanon. 
22. Isaac Ben SolimanEzz El Din. Nutrition and Medicine, published Beirut, Lebanon.

23. Richard Gerber. Vibrational Medicine: Newchoices for healing ourselves. Bear \&Company. Santa Fe, NM 87504-2860.

Citation: Almoez LeDinEllah M. S. Eltouny. The Treatment of HIV by Vibrational Herbal Medicine.Archives of Clinical and Medical Case Reports 3 (2019): 11-22.

(C) $P$ Bis article is an open access article distributed under the terms and conditions of the
Creative Commons Attribution (CC-BY) license 4.0 